\title{
PEMETAAN KABUPATEN/KOTA DI PROVINSI JAWA BARAT BERDASARKAN NILAI UJIAN NASIONAL SMA DAN AKREDITASI SEKOLAH
}

\author{
Charles E. Mongi ${ }^{1)}$ \\ 1) Jurusan Matematika FMIPA Universitas Samratulangi, Manado \\ email: charlesmongi@ymail.com
}

\begin{abstract}
ABSTRAK
Pendidikan memiliki peranan yang sangat penting bagi setiap individu mulai dari usia dini sampai usia lanjut. Jenjang pendidikan terdiri dari jenjang pendidikan dasar, menengah dan tinggi. Penelitian ini membahas posisi relatif kabupaten/kota di Provinsi Jawa Barat terhadap nilai UN dan akreditasi sekolah menengah atas dan penggerombolan sekolah di Provinsi Jawa Barat. Hasil analisis biplot menghasilkan tujuh kelompok sekolah. Kelompok pertama berada di rata-rata nilai UN dan akreditasi. Kelompok kedua cenderung rendah pada nilai UN dan akreditasi. Kelompok ketiga rendah pada nilai UN. Kelompok empat tinggi pada nilai akreditasi. Kelompok lima tinggi pada nilai UN. Kelompok enam cenderung tinggi pada nilai UN eksak. Kelompok tujuh rendah pada nilai UN dan akreditasi.
\end{abstract}

Kata kunci: Nilai UN, Akreditasi, Biplot

\section{MAPPING SENIOR HIGH SCHOOL IN WEST JAVA BASED NATIONAL EXAMINATION VALUE AND SCHOOL ACCREDITATION}

\begin{abstract}
Education has important role for individuals from childhood to the elderly. Educational levels consists primary education, secondary education and higher education. This study discussed the relative position of the districts in West Java Province throughout the national examination and high school accreditationas as well school clustering in West Java Province. Result of biplot analysis generated seven groups, first group were in the average national examination and accreditation. Second group were inclined low in national examination and also accreditation. The third group has a low national examination scores. The fourth group had a high score on the value of accreditation. Fifth group had a high value on national examination scores. The sixth group had inclined high national examination scores especially in science subjects. The seventh group had a low value on national examination and accreditation scores.
\end{abstract}

Keywords: National Examination value, Accreditation, Biplot

\section{PENDAHULUAN}

Pendidikan memiliki peranan yang sangat penting bagi setiap individu baik dari usia dini sampai dengan usia lanjut. Setiap orang membutuhkan pendidikan untuk mengembangkan kemampuan intelektual, emosional maupun spiritual. Menurut Kamus Besar Bahasa Indonesia (Depdiknas, 2008), pendidikan adalah proses pengubahan sikap dan tata laku seseorang atau kelompok orang dalam usaha mendewasakan manusia melalui upaya pengajaran dan pelatihan. Pendidikan bukanlah sekedar pelatihan dan pelatihan tidak boleh mereduksi makna pendidikan, dimana pendidikan merupakan dasar dari proses pembangunan sebuah negara (Saefuddin, 2010).

Jalur pendidikan di Indonesia terdiri atas pendidikan formal, nonformal dan informal yang dapat saling melengkapi. Pendidikan formal jenjangnya terdiri atas pendidikan dasar, pendidikan menengah dan pendidikan tinggi. Pendidikan menengah berbentuk Sekolah Menengah Atas (SMA), Madrasah Aliyah (MA), Sekolah Menengah Kejuruan (SMK), dan Madrasah Aliyah 
kejuruan (MAK) atau bentuk lainnya yang sederajat (DPR RI, 2003). Kualitas dari suatu sekolah salah satunya dapat diukur dengan kompetensi lulusan yang baik dengan melihat nilai ujian sekolah, nilai rapor dan nilai ujian nasional (UN).

Pelaksanaan UN diawali dengan ujian negara yang pertama kali dilaksanakan tahun 1965 kemudian berganti nama dan teknis pelaksanaan (Depdiknas, 2006). Pada tahun 2011 UN pernilaiannya terdiri dari mata pelajaran Bahasa Indonesia, Bahasa Inggris, Matematika, dan mata pelajaran jurusan IPA, IPS, atau Bahasa. Nilai UN merupakan $60 \%$ syarat kelulusan disamping $40 \%$ dari nilai sekolah (Depdiknas, 2010). Kualitas suatu sekolah juga dilihat dari akreditasi sekolah yang merupakan proses penilaian dari eksternal sekolah yang dilaksanakan oleh badan akreditasi nasional sekolah dan madrasah.

Akreditasi merupakan proses penilaian sekolah yang dilaksanakan secara independen oleh badan akreditasi nasional sekolah dan madrasah (BAN S/M). Akreditasi dilakukan untuk menentukan kelayakan program dan satuan pendidikan pada jalur pendidikan formal dan non formal pada setiap jenjang dan jenis pendidikan (DPR RI, 2003). Menurut Ahmad (2010), akreditasi dilaksanakan dengan maksud untuk kepentingan pengetahuan, yakni sebagai informasi bagi semua pihak tentang kelayakan dan kinerja sekolah dilihat dari berbagai unsur yang terkait, dengan mengacu kepada standar nasional pendidikan.

Dalam BPS (2012) Jawa Barat merupakan Provinsi yang berbatasan dengan ibukota negara, yang berakibat ikut merasakan dampak positif dan negatif pembangunan di DKI Jakarta. Dari aspek jumlah penduduk, Jawa Barat merupakan yang terbesar dari 34 provinsi di Indonesia. Jumlah penduduk yang banyak akan meningkatkan jumlah penduduk yang membutuhkan pendidikan. Angka partisipasi sekolah Provinsi Jawa Barat yaitu 55,69 persen berada dibawah angka nasional 61,06 hal ini menarik untuk dilakukan penelitian lebih lanjut.

Penelitian terkait yang dilakukan oleh Sujita (2009) tentang pemetaan mutu sekolah yang sesuai dengan ujian nasional SMU di Kabupaten dan Kota Malang menunjukkan terdapat korelasi yang tinggi antara mutu lulusan dengan mutu masukan, sosial ekonomi orang tua dan fasilitas belajar.

Perumusan masalah dalam penelitian ini adalah bagaimana keterkaitan antara nilai UN dengan peringkat akreditasi pada Kabupaten/Kota di Privinsi Jawa Barat. Analisis biplot digunakan untuk melihat bagaimana posisi relatif antara Kabupaten/Kota dengan peubah-peubah nilai UN dan nilai akreditasi secara bersama. Penggerombolan dilakukan dengan menggunakan teknik berhirarki berdasarkan nilai UN.

Tujuan dari penelitian ini adalah:

1. Melihat posisi relatif Kabupaten/Kota di Jawa Barat terhadap nilai UN dan akreditasi sekolah.

2. Menggerombolkan sekolah-sekolah di Provinsi Jawa Barat berdasarkan nilai Ujian Nasional.

\section{METODE}

\section{Sumber Data}

1. Data nilai ujian nasional SMA tahun ajaran 2010/2011. SMA yang dipilih adalah SMA negeri yang ada di Provinsi Jawa Barat. Nilai ujian nasional berupa nilai mata ajaran pada program IPA (Ilmu Pengetahuan Alam) yaitu, Bahasa Indonesia, Bahasa Inggris, Matematika, Fisika, Kimia, dan Biologi. Data tersebut di dapat dari Balitbang Kemendikbud RI. Data nilai ujian nasional adalah skor dengan nilai terendah nol dan nilai yang tertinggi 10. Nilai tersebut dikalikan dengan 10 sehingga skornya menjadi antara nol sampai 100.

2. Data nilai akreditasi SMA yang ada di Provinsi Jawa Barat sampai dengan Maret 2013. Data tersebut dapat diakses melalui situs Badan Akreditasi Nasional Sekolah/Madrasah (BAN-S/M). Data akreditasi terdiri dari nilai (skor 0-100) dan peringkat (skor A,B,C) akreditasi, nilai berupa numerik dan peringkat berupa kategorik dengan kriteria nilai kurang dari 70 mendapat peringkat $\mathrm{C}, 70$ sampai 84,99 mendapat peringkat $B$, dan peringkat A lebih dari sama dengan 85 . Peubah-peubah yang diamati seperti dalam Tabel 1. 
Tabel 1 Peubah-peubah yang diamati

\begin{tabular}{lllc}
\hline \multicolumn{1}{c}{ Mata Pelajaran } & \multicolumn{1}{c}{ Kode } & \multicolumn{1}{c}{ Standar Akreditasi } & Kode \\
\hline Bahasa Indonesia & BIN & Isi & A1 \\
Bahasa Inggris & ING & Proses & A2 \\
Matematika & MAT & Kompetensi Lulusan & A3 \\
Fisika & FIS & Tenaga pendidik dan kependidikan & A4 \\
Kimia & KIM & Sarana dan prasarana & A5 \\
Biologi & BIO & Pengelolaan & A6 \\
& & Pembiayaan & A7 \\
& & Penilaian & A8 \\
\hline
\end{tabular}

\section{Metode Analisis}

Nilai ujian nasional sebelum di analisis terlebih dahulu diubah skalanya supaya sama dengan skor nilai akreditasi dengan mengalikan 10. Selanjutnya tahapan analisis adalah sebagai berikut:

1. Deskripsi

Analisis deskripsi dilakukan untuk melihat gambaran rata-rata dan persentase nilai UN dan akreditasi sekolah di setiap Kabupaten/Kota.

2. Analisis Biplot

Analisis biplot dilakukan untuk melihat karakteristik Kabupaten/Kota berdasarkan capaian standar akreditasi dan skor UN. Analisis biplot langkahlangkahnya adalah sebagai berikut (Jolliffe, 2002):

a. Membuat matriks data $\mathbf{X}$ dengan baris adalah objek yaitu Kabupaten/Kota dan kolom adalah peubah yaitu skor UN digabung dengan nilai akreditasi.

b. Menghitung akar ciri dan vektor ciri dari matriks $\mathbf{X}^{\prime} \mathbf{X}$.

c. Menguraikan matriks $\mathbf{X}=\mathbf{U} \mathbf{\Lambda} \mathbf{V}^{\prime}$.

d. Menghitung koordinat objek dan peubah:

- Menjabarkan matriks $\mathbf{X}=\mathbf{U} \boldsymbol{\Lambda}^{\alpha} \boldsymbol{\Lambda}^{1-}$ ${ }^{\alpha} \mathbf{V}$ '.

- Memisalkan $\mathbf{G}=\mathbf{U} \boldsymbol{\Lambda}^{\alpha}$ dan $\mathbf{H}^{\prime}=\boldsymbol{\Lambda}^{1-}$ ${ }^{\alpha} \mathbf{V}$ '.

- Menghitung matriks $\mathbf{G}$ dan $\mathbf{H}^{\prime}$ dengan $\alpha=0$.

- Mengambil 2 kolom pertama dari matriks $\mathbf{G}$ sebagai koordinat objek pengamatan dan 2 baris pertama dari matriks H' sebagai koordinat peubah.

\section{HASIL DAN PEMBAHASAN Karakteritik Sekolah Menurut Peringkat Akreditasi}

Sekolah yang diteliti berjumlah 424 merupakan sekolah negeri di Provinsi Jawa Barat. Nilai UN merupakan rata-rata setiap sekolah terhadap masing-masing mata pelajaran dengan sekolah yang peringkat akreditasi A lebih tinggi nilainya dengan sekolah yang peringkat akreditasinya B dan $\mathrm{C}$, hal yang sama dengan peringkat akreditasi B terhadap yang C. Sekolah yang tidak terakreditasi memiliki nilai lebih tinggi dengan sekolah yang terakreditasi A pada beberapa mata pelajaran, yaitu bahasa inggris, kimia dan biologi. Sekolah yang tidak terakreditasi lebih tinggi nilainya dengan yang terakreditasi karena jumlahnya yang sedikit hanya 3 sekolah. Gambar capaian nilai UN dalam diagram batang dapat dilihat pada Gambar 1(a).

Nilai akreditasi yang dihitung adalah 8 standar penilaian terhadap masing-masing peringkat akreditasi. Kedelapan standar akreditasi nilainya cenderung lebih tinggi untuk sekolah yang berperingkat akreditasi A terhadap B dan B terhadap C. Hal ini sesuai karena peringkat akreditasi diambil berdasarkan nilai standar akreditasi. Nilai tertinggi adalah standar pembiayaan untuk sekolah peringkat akreditasi A dan nilai terendah adalah standar sarana dan prasarana untuk sekolah peringkat akreditasi $\mathrm{C}$ terlihat dalam Gambar 1(b).

Rata-rata nilai UN dan nilai akreditasi menunjukkan hal yang konsisten bahwa sekolah dengan peringkat akreditasi A cenderung lebih tinggi nilainya dengan sekolah yang nilai akreditasi B. Hal yang sama untuk sekolah dengan peringkat akreditasi B terhadap sekolah peringkat akreditasi C. 


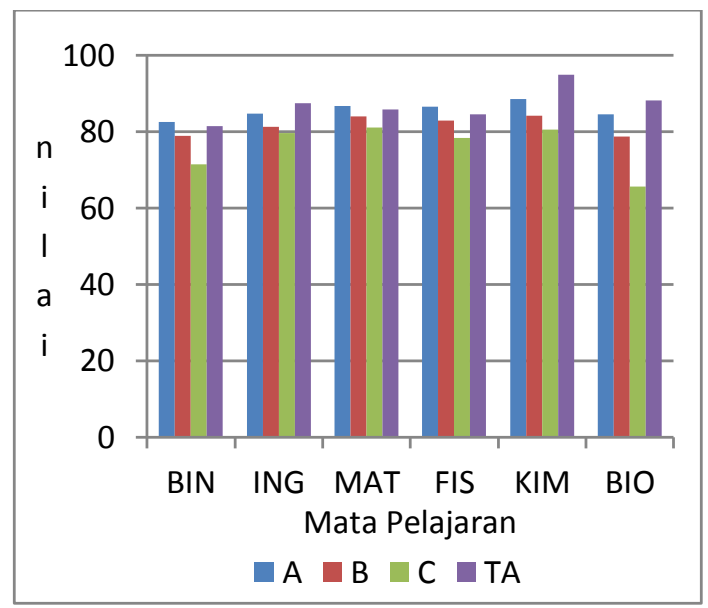

(a)

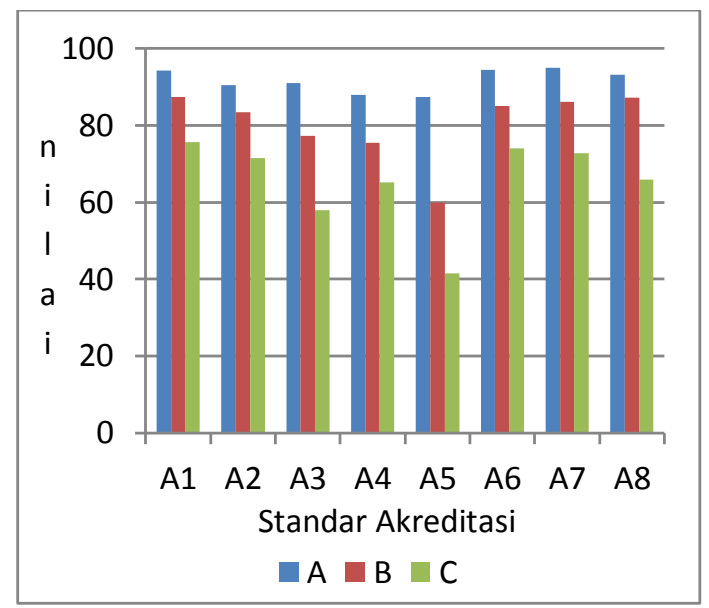

(b)

Gambar 1 (a) Rata-rata nilai UN sekolah berdasarkan peringkat akreditasi sekolah (b) Rata-rata nilai standar akreditasi sekolah berdasarkan peringkat akreditasi sekolah

Tabel 2 Ringkasan nilai UN tertinggi dan terendah menurut Kabupaten/Kota

\begin{tabular}{|c|c|c|c|c|c|c|c|}
\hline & & \multicolumn{6}{|c|}{ Mata Pelajaran } \\
\hline & & BIN & ING & MAT & FIS & KIM & $\mathrm{BIO}$ \\
\hline \multirow{3}{*}{ Terendah } & Nilai & 74.56 & 71.92 & 77.90 & 77.51 & 82.33 & 72.80 \\
\hline & $\mathrm{Kab} /$ & $\mathrm{Kab}$ & $\mathrm{Kab}$ & Kota & \multirow{2}{*}{\multicolumn{3}{|c|}{ Kab Bogor }} \\
\hline & Kota & Cianjur & Karawang & Depok & & & \\
\hline \multirow{3}{*}{ Tertinggi } & Nilai & 87.83 & 92.39 & 94.43 & 95.20 & 95.22 & 96.33 \\
\hline & $\mathrm{Kab} /$ & $\mathrm{Kab}$ & Kota & Kota & Kota & Kota & Kota \\
\hline & Kota & Cirebon & Bogor & Tasikmalaya & Banjar & Cirebon & Tasikmalaya \\
\hline
\end{tabular}

Tabel 3 Ringkasan nilai akreditasi tertinggi dan terendah menurut kabupaten/kota

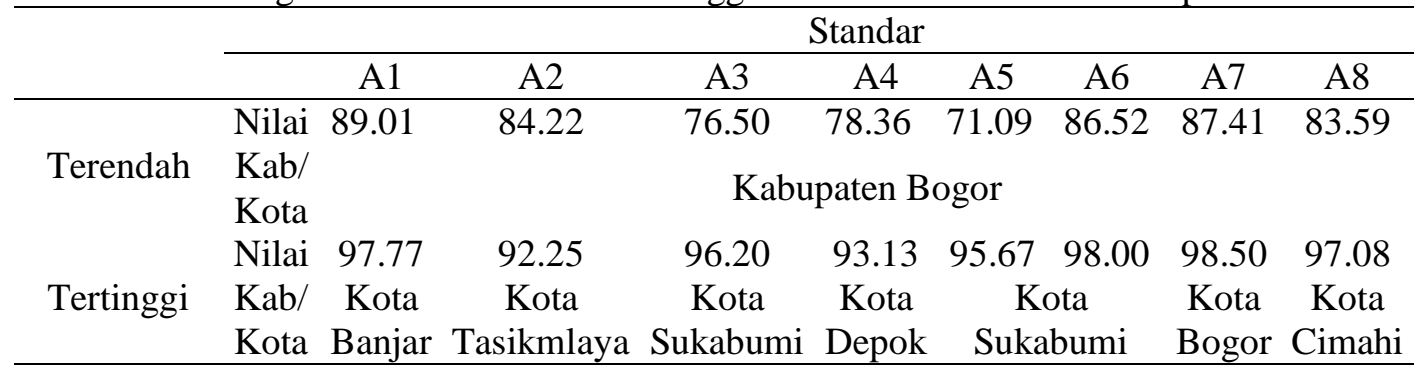

\section{Karakteristik Kabupaten/Kota menurut Nilai UN dan Standar Akreditasi}

Kabupaten dan kota di Provinsi Jawa Barat jumlahnya 26 yang terdiri dari 17 kabupaten dan 9 kota. Tabel 2 menunjukkan nilai mata pelajaran Bahasa Indonesia tertinggi terdapat di Kabupaten Cirebon dan terendah di kabupaten Cianjur. Nilai mata pelajaran Bahasa Inggris tertinggi di Kota Bogor terendah di Kabupaten Karawang. Nilai mata pelajaran Matematika tertinggi di Kota Tasikmalaya dan terendah di Kota Depok. Nilai mata pelajaran Fisika tertinggi di Kota Banjar dan terendah di Kabupaten Bogor. Nilai mata pelajaran Kimia tertinggi di Kota Cirebon dan terendah di Kabupaten Bogor. Nilai mata pelajaran Biologi tertinggi di Kota Tasikmalaya dan terendah di Kabupaten Bogor. Nilai UN tertinggi tersebar di tiga daerah kota yaitu Kota Bogor, Cirebon dan Tasikmalaya. Nilai UN terendah tersebar di tiga Kabupaten dan satu Kota.

Tabel 3 menunjukkan nilai tertinggi untuk standar isi terdapat di Kota banjar, standar proses di Kota Tasikmalaya, standar kompetensi lulusan di Kota Sukabumi, standar tenaga pendidikan dan kependidikan di Kota Depok, standar sarana dan prasarana serta standar pengelolaan di Kota Sukabumi, standar pembiayaan di Kota Bogor, standar 
penilaian di Kota Cimahi. Nilai terendah untuk kedelapan standar berada di Kabupaten Bogor. Hal ini menunjukkan nilai kedelapan standar akreditasi nilai tertinggi semuanya berada di daerah Kota, dan nilai terendah semuanya di Kabupaten Bogor.

\section{Pemetaan Kabupaten/Kota Berdasarkan Karakteristik Capaian Nilai UN dan Standar Nasional Pendidikan}

Analisis Biplot dilakukan antara objek yaitu 26 Kabupaten/Kota dan peubah yaitu 6 nilai mata pelajaran dan 8 nilai standar akreditasi secara bersama, hasilnya seperti dalam Gambar 2. Keragaman antar peubah mata pelajaran hampir sama kecuali Bahasa Inggris yang lebih kecil dibandingkan dengan mata pelajaran yang lainnya dimana panjang vektornya lebih pendek. Untuk peubah standar akreditasi keragamannya juga hampir sama kecuali standar isi yang keragamannya lebih kecil dan standar sarana dan prasarana keragamannya lebih besar.

Korelasi antar peubah terlihat antara mata pelajaran Matematika, Fisika dan Kimia terdapat korelasi yang tinggi, mata pelajaran bahasa Indonesia, bahasa Inggris, dan Biologi juga memiliki korelasi yang tinggi. Sedangkan untuk peubah standar akreditasi yang memiliki korelasi yang tinggi adalah antara standar proses, standar kompetensi lulusan, standar tenaga pendidikan dan kependidikan, dan standar penilaian.

Objek dapat dikelompokkan dalam 7 kelompok dengan menggunakan garis kontur luar disajikan dalam Tabel 4. Kelompok pertama kabupaten Kuningan, Sumedang dan Indramayu berada di rata-rata nilai UN dan akreditasi. Kelompok kedua cenderung rendah dalam nilai UN dan akreditasi yaitu Kabupaten Sukabumi, Cianjur, Bandung, Garut, Tasikmalaya, Subang, Purwakarta, Bekasi, Bandung barat dan Kota Bekasi. Kelompok ketiga yaitu Kabupaten Karawang dan Kota Depok rendah dalam nilai UN. Kota Bogor, Sukabumi, Bandung dan Cimahi termasuk kelompok empat tinggi pada nilai akreditasi. Kelompok lima yaitu Kota Cirebon, Tasikmalaya dan Banjar tinggi dalam nilai UN. Kelompok enam cenderung tinggi pada nilai UN eksak yaitu Kabupaten Ciamis, Cirebon dan Majalengka. Kelompok tujuh yaitu Kabupaten Bogor rendah pada nilai UN dan akreditasi sekolah.

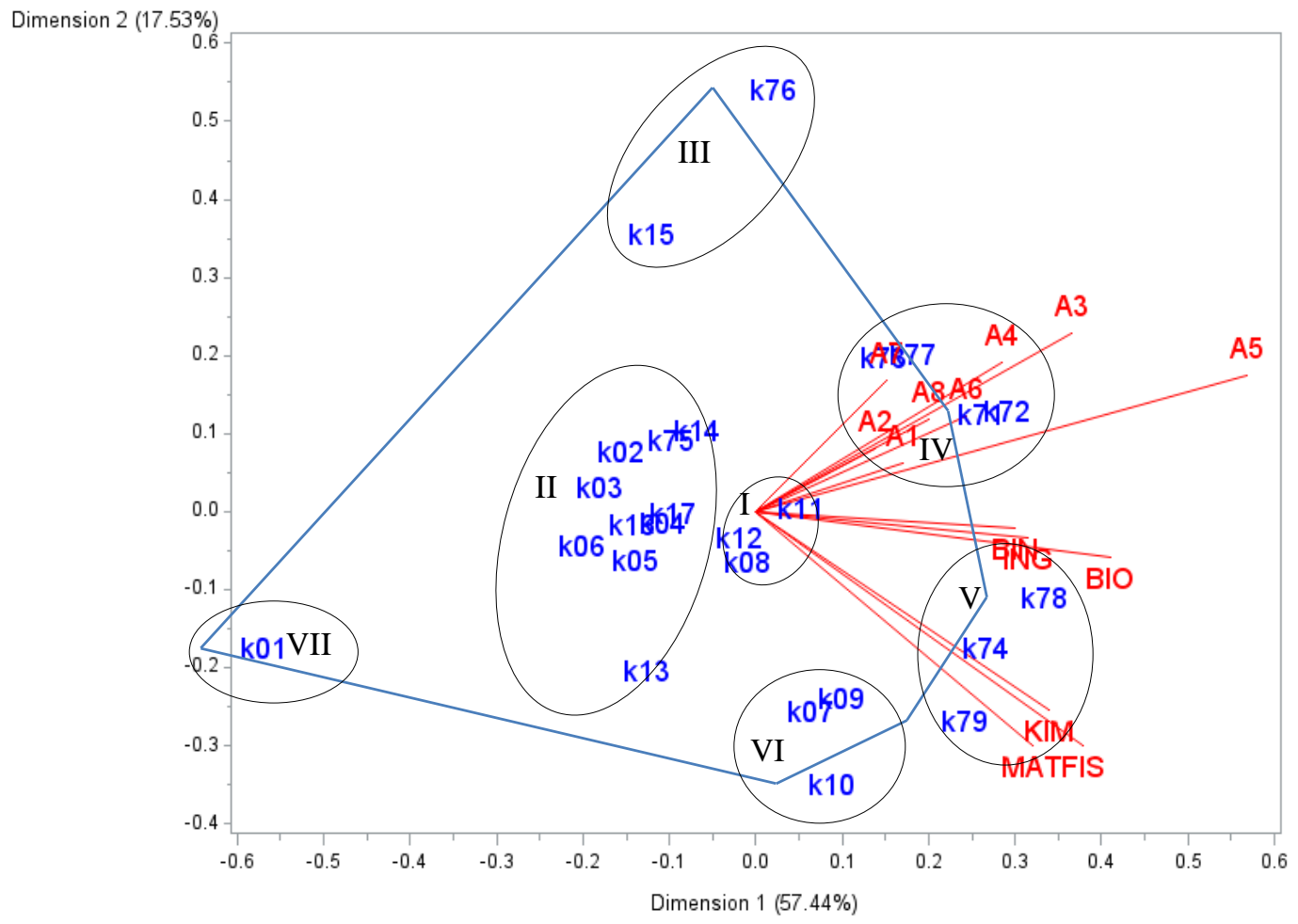

Gambar 2 Biplot antara Kabupaten/Kota dengan nilai UN dan Akreditasi 
Tabel 4 Pengelompokan kabupaten hasil analisis biplot

\begin{tabular}{|c|c|c|}
\hline Kelompok & Kabupaten / Kota & Karakteristik \\
\hline Kelompok 1 & $\begin{array}{l}\text { Kab Kuningan, Kab Sumedang, Kab } \\
\text { Indramayu }\end{array}$ & $\begin{array}{l}\text { Rata-rata pada UN } \\
\text { dan Akreditasi }\end{array}$ \\
\hline Kelompok 2 & $\begin{array}{l}\text { Kab Sukabumi, Kab Cianjur, Kab Bandung, } \\
\text { Kab Garut, Kab Tasikmalaya, Kab Subang, } \\
\text { Kab Purwakarta, Kab Bekasi, Kab Bandung } \\
\text { barat, Kota Bekasi, }\end{array}$ & $\begin{array}{l}\text { Cenderung rendah } \\
\text { pada UN dan } \\
\text { Akreditasi }\end{array}$ \\
\hline Kelompok 3 & Kab Karawang, Kota Depok & Rendah pada UN \\
\hline Kelompok 4 & $\begin{array}{l}\text { Kota Bogor, Kota Sukabumi, Kota Bandung, } \\
\text { Kota Cimahi }\end{array}$ & $\begin{array}{l}\text { Tinggi pada } \\
\text { Akreditasi }\end{array}$ \\
\hline Kelompok 5 & $\begin{array}{l}\text { Kota Cirebon, Kota Tasikmalaya, Kota } \\
\text { Banjar }\end{array}$ & Tinggi pada UN \\
\hline Kelompok 6 & Kab Ciamis, Kab Cirebon, Kab Majalengka & $\begin{array}{l}\text { Cenderung tinggi pada } \\
\text { UN eksak }\end{array}$ \\
\hline Kelompok 7 & Kab Bogor & $\begin{array}{l}\text { Rendah pada UN dan } \\
\text { Akreditasi }\end{array}$ \\
\hline
\end{tabular}

\section{PENUTUP}

\section{Kesimpulan}

Posisi relatif kabupaten/kota di Jawa Barat dapat dikelompokkan dalam tujuh kelompok, kelompok pertama berada di rata-rata nilai UN dan akreditasi, kelompok kedua cenderung rendah pada UN dan akreditasi, kelompok ketiga rendah pada nilai UN, kelompok empat tinggi pada nilai akreditasi, kelompok lima tinggi pada nilai $\mathrm{UN}$, kelompok enam cenderung tinggi pada nilai UN eksak, dan kelompok ketujuh rendah pada nilai UN dan akreditasi.

\section{Saran}

Penelitian ini hanya terbatas pada SMA Negeri program IPA sehingga perlu dilakukan kajian untuk sekolah-sekolah swasta dan program ilmu pengetahuan sosial dan bahasa.

\section{DAFTAR PUSTAKA}

Ahmad S. 2010. "Akreditasi Sekolah Muara Peningkatan Mutu Pendidikan". http://www.univpgripalembang.ac.id: 2095/penelitian/akreditasisekolahmu arapeningkatanmutu-2.pdf (diunduh 23 Januari 2014).

BPS. 2012. "Indikator kesejahteraan rakyat provinsi Jawa barat 2011". Bandung: Badan Pusat Statistik Provinsi Jawa Barat.

Depdiknas. 2006. "Kilas Balik Pendidikan Nasional 2006", Jakarta: Pusat Informasi dan Humas Depdiknas.
Depdiknas. 2008. "Kamus Besar Bahasa Indonesia". Jakarta: Pusat Bahasa Depdiknas.

Depdiknas. 2010. "Peraturan Menteri Pendidikan Nasional No. 45 tentang kriteria kelulusan peserta didik SMP/MTS, SMPLB, SMA/MA, SMALB, dan SMK tahun pelajaran 2010/2011".

DPR RI. 2003. "Undang-undang No. 20 tentang sistem pendidikan nasional". http://www.dpr.go.id/id/undangundang/2003/20/uu /SistemPendidikan-Nasional (diunduh 26 Mei 2014)

Jolliffe IT. 2002. "Principal Component Analysis $2^{\text {nd }}$ edition". New York: Springer-Verlag.

Saefuddin A. 2010. "Percikan Pemikiran: Kepemimpinan dan Pendidikan". Bogor: IPB Pr.

Sujita. 2009. "Analisis Biplot untuk Memetakan Mutu Sekolah yang Sesuai dengan Nilai Ujian Nasional" [tesis]. Bogor: Matematika terapan. FMIPA IPB. 